\title{
Impact of Saline Water on Growth of Olive Varieties in Tunnel
}

\author{
Muhammad Arshadullah ${ }^{1 *}$, Syeda Sana Aamir ${ }^{1}$, Bilal Adil $^{2}$, Hussnain Haider ${ }^{2}$, \\ Imdad Ali Mahmood ${ }^{1}$, Badar-uz-Zaman ${ }^{1}$, Syed Ishtiaq Hyder ${ }^{1}$, Abdul Sattar Anjum ${ }^{1}$ \\ ${ }^{I}$ National Agricultural Research Centre, Park Road, Islamabad-45500, Pakistan \\ ${ }^{2}$ Institute of Soil Sciences, University of Arid Agriculture, Rawalpindi, Punjab, Pakistan
}

*Corresponding Author: Muhammad Arshadullah, National Agricultural Research Centre, Park Road, Islamabad-45500, Pakistan

\begin{abstract}
The study was carried out at NARC Islamabad during August, 2017 to October, 2017 to investigate the impact of salinity on growth 4 olive varieties i.e. Uslo, Coratina, Carolea and Moraila having 3 months sprouted olive cuttings under different saline water in tunnel. Six levels of saline water artificially developed $\left(E C w=0,2,4,6,8,10 \mathrm{dSm}^{-1}\right)$. Completely randomized design was applied with three replications. Olive cuttings were irrigated with six saline water three times in a week. Results of this study indicated that Cortiana Olive variety attained the highest values in stem diameter, root fresh weight, root dry weight and stem dry weight growth parameters while Carolea Olive variety attained the best in roots dry weight, leaf fresh weight, leaf dry weight, shoot fresh weight, shoot dry weight and leaf area under the irrigation of different saline water. Chlorophyll contents were the highest in Uslo olive variety in all saline water application.
\end{abstract}

Keywords: Uslo, Coratina, Carolea, Moraila olive varieties, saline water and olive growth

\section{INTRODUCTION}

Salinity is one of the most important environmental factors, limiting crop production in arid and semiarid regions (Sepaskhah and Yarami, 2010). The deleterious effects of salinity on plant growth are associated with low osmotic potential of soil solution (water stress), nutritional imbalance, specific ion effect (salt stress), or a combination of these factors (Ashraf, 1994; Marschner, 1995). Toxicity of $\mathrm{Na}^{+}$in metabolic processes results from its ability to compete with $\mathrm{K}^{+}$for binding sites and to inactivate enzymes and essential cellular functions and, consequently, crops growing in saline soils may suffer the dual injury of $\mathrm{Na}+$ toxicity and low $\mathrm{K}^{+}$concentrations (Munns and Tester, 2008). For most plants to tolerate salinity, $\mathrm{Na}+$ and $\mathrm{Cl}^{-}$uptake must be restricted while maintaining the uptake of macro nutrients such as $\mathrm{K}+, \mathrm{NO}_{3}^{-}$and $\mathrm{Ca}^{2+}$ (Tavakkoli et al., 2011).

Irrigated olive orchards have expanded in the last decades in many areas of the world and in particular in the Mediterranean region, where $98 \%$ of the world's olive oil is produced. An increasing proportion of these orchards is being irrigated with low-quality waters due to the growing competition of freshwater by other users, population growth and climate change (Cimato et al. 2010; Chartzoulakis, 2005). Due to the expansion of olive orchards irrigated with saline waters, a proper knowledge of response of olive to salinity is essential. However, existing data on the effects of salinity on growth and yield of olive are scarce, especially for long-term experiments under field conditions (Aragüésetal. 2005; Cimato et al. 2010; Gucci and Tattini 1997; Melgar et al. 2009; Wiesman et al. 2004).

Olive is considered moderately tolerant to salinity, with threshold ECe values ( $\left.\mathrm{dS} \mathrm{m} \mathrm{m}^{-1}\right)$ that vary among authors: 4-6 (Bernstein 1964), 3-6 (Maas and Hoffman 1977), 1.2-2.5 (Hassan et al. 2000), 2.7 (Soltanpour and Follet 2001), and 4.0 (Aragüés et al. 2004). Based on the absolute slope of the response functions, Araguiés et al. (2004) provided a value of $12 \%$ for the growth of young olive, whereas Hassan et al. (2000) reported values from 3.4\% to 5.2\% for fruit yield of three olive cultivars. These authors also concluded that vegetative growth was more tolerant to salinity than fruit yield production.

Melgar et al. (2009) reported that mature trees of the tolerant cultivar Picual drip-irrigated under Mediterranean climate (mean annual precipitation around $700 \mathrm{~mm}$ ) allowed using high saline 
irrigation waters (up to $10 \mathrm{dS} \mathrm{m}^{-1}$ ) for a long time (nine years) without affecting growth and yield. Winter leaching by rainfall of the salts accumulated in the root zone during the irrigation seasons was the main reason for the absence of negative effects with such high saline waters. This result clearly shows that the establishment of the salinity tolerance of olive (or any other crop) should be based on root zone soil salinity rather than irrigation water salinity. It has been reported that under salinity conditions, excessive accumulation of ions in the cytoplasm or chloroplast of mesophyll cells reduces the photosynthesis rate (Dubey, 2005).

The use of saline water for irrigation requires an adequate understanding of how salts affect soil characteristics and plant performance (Chartzoulakis et al. 2002). According to the incapacity to grow on high salt medium, plants have been classified as glycophytes or halophytes. Most plants are glycophytes and cannot tolerate salt stress (Parvaiz and Satyawati 2008). Consequently, salinity is an ever-present threat to agriculture, especially in areas where secondary salinization has developed through irrigation (Flowers and Flowers 2005). The deleterious effects of salinity on plant growth are associated with: (1) low osmotic potential of soil solution (water stress); (2) nutritional imbalance; (3) specific ion effect (salt stress) or (4) a combination of these factors. During the onset and development of salt stress within a plant, all the major processes such as photosynthesis, protein synthesis and energy and lipid metabolisms are affected. The earliest response is a reduction in the rate of leaf surface expansion followed by cessation of expansion as the stress intensifies but growth resumes when the stress is relieved (Parvaiz and Satyawati 2008). Hence, an effective way to use saline lands should be found by the cultivation of tolerant cultivars or other agro techniques (Tabatabaei, 2006). Attempts to improve the salt tolerance of crops have met with very limited success, due to the complexity of the trait, both genetically and physiologically influenced (Flowers and Flowers 2005). The objective of this work was to evaluate the response of olive plant growth.

\section{MATERIAL AND MeTHOdS}

The study was carried out at NARC Islamabad during August, 2017 to October, 2017 to investigate the impact of salinity on growth of 3 months sprouted olive cuttings of 4 olive varieties i.e. Uslo, Coratina, Carolea and Moraila under different saline water in tunnel. Six levels of saline water artificially developed $\left(\mathrm{ECW}=0,2,4,6,8,10 \mathrm{dSm}^{-1}\right)$. Completely randomized design was applied with three replications. Olive cuttings were irrigated with six saline water three times in a week.

\section{RESULTS AND DISCUSSIONS}

\subsection{Saline Water on Olive Growth}

Table-1 showed results of stem diameter affected by different saline waters within three olive varieties. Overall Coratina olive variety gained the highest stem diameter $(8.56 \mathrm{~mm})$ with the irrigation of different levels of saline water.

Olive roots fresh weight was also affected by different saline waters within three olive varieties as indicated in table-1. However, Coratina olive variety gained the highest roots fresh weight $(0.83 \mathrm{gm})$ with the irrigation of different levels of saline water.

Saline water irrigation influenced the Olive roots dry weight was of three olive varieties as mentioned in table-1. Carolea olive variety gained the highest roots dry weight $(0.21 \mathrm{gm})$ under the irrigation of different levels of saline water.

Olive varieties and saline water irrigation inclined the Olive stem fresh weight (table-1). Coratina olive variety attained the top position in the stem fresh weight $(20.05 \mathrm{gm})$ irrigating the olive plants with different levels of saline water.

Olive stem dry weight of three olive varieties was differed with utilization of different saline water as shown in table-1.Highest olive stem dry weight $(12.36 \mathrm{gm})$ was attained by Coratina olive variety under irrigation by different levels of saline water.

Data indicated in table-2 regarding olive leaf fresh weight described the effects of saline water irrigations. Highest olive leaf fresh weight $(2.51 \mathrm{gm})$ was received with Carolea olive variety by irrigation of different levels of saline water. 
Data presented in table-2 related to olive leaf dry showed the influences of saline water irrigations. Carolea olive variety gained the highest olive leaf dry weight (1.06 gm) under irrigation of different levels of saline water.

Data regarding effect on olive shoot fresh weight by saline water was mentioned in table-2. Carolea olive variety gained the maximum olive shoot fresh weight $(1.15 \mathrm{gm})$ under irrigation of different levels of saline water.

Olive shoot dry weight influence by saline irrigations was observed in table-2. Overall, Carolea olive variety attained the upper limit of olive shoot dry weight $(0.49 \mathrm{gm})$ for different levels of saline water irrigation.

Chlorophyll contents parameter in plant growth is the main due to photosynthesis process. Chlorophyll contents data was presented in table-2 showing variation among treatments. However, the highest chlorophyll contents $(77.40 \%)$ were measured by Uslo olive variety with the treatments of saline waters.

Leaf area in plant is the detrimental factor in plant growth as well as in fruit development. Leaf area data was presented in table- 2 describing variation among treatments and olive varieties. Resultantly the highest leaf area $\left(26.61 \mathrm{~cm}^{2}\right)$ was measured by Carolea olive variety with the saline water irrigations.

Table1. Impact of brackish water on stem diameter, stem fresh weight, stem dry weight, Root fresh weight and Root dry weight of olive plants

\begin{tabular}{|c|c|c|c|c|c|c|c|c|c|c|c|c|c|c|c|c|c|c|c|c|}
\hline \multirow[t]{2}{*}{ Treatments } & \multicolumn{4}{|c|}{\begin{tabular}{|l|}
$\begin{array}{l}\text { Stem Diameter } \\
(\mathbf{m m})\end{array}$ \\
\end{tabular}} & \multicolumn{4}{|c|}{\begin{tabular}{|l} 
Stem Fresh \\
Weight (g)
\end{tabular}} & \multicolumn{4}{|c|}{$\begin{array}{l}\text { Stem Dry } \\
\text { Weight(g) }\end{array}$} & \multicolumn{4}{|c|}{ Root Fresh Weight(g) } & \multicolumn{4}{|c|}{\begin{tabular}{|l|} 
Stem Dry \\
Weight(g)
\end{tabular}} \\
\hline & V1 & $\mathbf{V 2}$ & $\mathbf{V 3}$ & V4 & V1 & V2 & $\mathbf{V 3}$ & V4 & V1 & V2 & V3 & V4 & V1 & $\mathbf{V 2}$ & $\mathbf{V 3}$ & V4 & V1 & $\mathbf{V 2}$ & $\mathbf{V 3}$ & V4 \\
\hline T1 & 4.67 & & & 8.64 & & 0 & 0 & 1.17 & 0.20 & 0 & 0 & 0.30 & 6.42 & 4.06 & & 5.75 & .62 & 2.0 & 1 & \\
\hline T2 & 6.88 & 6.76 & 7.11 & 6.32 & 0.22 & 0.64 & 0 & 0.42 & 0.07 & \begin{tabular}{|l|}
0.15 \\
\end{tabular} & 0 & 0.12 & 10.06 & 4.04 & \begin{tabular}{|l|l|}
5.98 \\
\end{tabular} & 4.21 & 4.93 & 2.08 & 2.73 & 2.9 \\
\hline $\mathbf{T 3}$ & 4.72 & 6.55 & 4.44 & 7.11 & 0.44 & 0.65 & 0.19 & 0.22 & 0.13 & 0.19 & 0.05 & 0.09 & 3.50 & 2.68 & 6.16 & 5.50 & 1.58 & 1.09 & 3.60 & 8 \\
\hline T4 & 5.76 & 7.91 & 6.76 & 6.74 & 0.55 & 2.10 & 0 & 0.39 & 0.22 & 0.62 & 0 & 0.06 & 5.21 & 8.24 & 4.36 & 9.40 & 3.0 & 4.60 & 2.13 & 4.4 \\
\hline T5 & 7.61 & 6. & 5.89 & 7.89 & 0.10 & 0 & 0 & 0.24 & & 0 & 0 & 0.09 & 5. & 6.84 & 9.78 & 7.12 & 3.75 & 2.68 & 4.63 & 3.67 \\
\hline T6 & 6.86 & 5.59 & 6.11 & 5.57 & 0.50 & 0.16 & 0 & 0.43 & 0.16 & 0.05 & 0 & 0.10 & 4.84 & 9.34 & 10.05 & 5.13 & 2.45 & 5.31 & 7.68 & 2.68 \\
\hline
\end{tabular}

$V 1=$ Coratina $V 2=$ Leccino $V 3=$ Nocellera V4=Frontoio

Table2. Impact of brackish water on leaf fresh weight, leaf dry weight, Shoot fresh weight, Shoot dry weight, Chlorophyll contents and leaf area of olive plants

\begin{tabular}{|c|c|c|c|c|c|c|c|c|c|c|c|c|c|c|c|c|c|c|c|c|c|c|c|c|}
\hline \multirow[t]{2}{*}{ Treatments } & \multicolumn{4}{|c|}{$\begin{array}{l}\text { Leaf Fresh } \\
\text { Weight(g) }\end{array}$} & \multicolumn{8}{|c|}{\begin{tabular}{|l|l|} 
Leaf Dry Weight(g) & $\begin{array}{l}\text { Shoot Fresh } \\
\text { Weight }(g)\end{array}$ \\
\end{tabular}} & \multicolumn{4}{|c|}{$\begin{array}{l}\text { Shoot Dry } \\
\text { Weight }(\mathrm{g})\end{array}$} & \multicolumn{4}{|c|}{$\begin{array}{l}\text { Chlorophyll } \\
\text { Contents (\%) }\end{array}$} & \multicolumn{4}{|c|}{ Leaf Area $\mathbf{C m}^{2}$ ) } \\
\hline & V1 & $\mathrm{V} 2$ & $\mathrm{V3}$ & V4 & V1 & V2 & V3 & $\mathrm{V4}$ & V1 & V2 & V3 & V4 & V1 & V2 & V3 & V4 & V1 & V2 & V3 & V4 & V1 & V2 & V3 & V4 \\
\hline T1 & 1.29 & 0.36 & & 2.78 & 0.27 & 0.09 & 0 & 1.58 & 0 & 0 & 0 & 1.18 & 0 & 0 & 0 & 0.31 & 48.1 & 57.9 & 0 & 67.7 & 19.142 & 21.521 & 0 & 21.586 \\
\hline T2 & 0.78 & 1.24 & & 1.26 & 0.24 & 0.32 & 0 & 0.56 & 0 & 1.02 & 0 & 0.65 & 0 & 0.33 & 0 & 0.27 & 55.8 & 61.2 & 0 & 69.3 & 21.664 & 23.641 & 0 & 19.231 \\
\hline T3 & 1.43 & 2.43 & 0.57 & 1.94 & 0.51 & 1.00 & 0.21 & 0.65 & 0.59 & 1.32 & 0.36 & 0.40 & 0.10 & 0.54 & 0.12 & 0.12 & 68.5 & 50.3 & 39.1 & 68.4 & 16.548 & 17.423 & 18.542 & 17.632 \\
\hline T4 & 0.92 & 4.36 & & 1.80 & 0.37 & 1.91 & 0 & 0.71 & 0 & 2.76 & 0 & 0.42 & 0 & 1.09 & 0 & 0.12 & 49.7 & 70.2 & 0 & 57.9 & 19.547 & 23.721 & 0 & 20.745 \\
\hline T5 & 0.30 & 0.88 & & 1.96 & 0.09 & 0.33 & 0 & 1.05 & 0 & 0.60 & 0 & 0.24 & 0 & 0.23 & 0 & 0.10 & 59.2 & 45.1 & 0 & 60.1 & 20.448 & 24.641 & 0 & 23.965 \\
\hline T6 & 0.93 & 1.43 & & 0.80 & 0.40 & 0.53 & & 0.32 & 0 & 0 & 0 & 0.91 & 0 & 0 & 0 & 0.39 & 54.3 & 47.7 & 0 & 62.8 & 20.632 & 22.117 & 0 & 22.342 \\
\hline
\end{tabular}

V1= Coratina $V 2=$ Leccino V3 =Nocellera V4=Frontoio

\section{CONClusion}

This experiment concluded that Cortiana Olive variety attained the highest values in stem diameter, root fresh weight, root dry weight and stem dry weight growth parameters while Carolea Olive variety attained the best in roots dry weight, leaf fresh weight, leaf dry weight, shoot fresh weight, shoot dry weight and leaf area under the irrigation of different saline water.

\section{REFERENCES}

Aragüés R, Puy J, Isidoro D.2004. Vegetative growth response of young olive trees (Olea europaea L., cv Arbequina) to soil salinity and waterlogging. Plant Soil 258: 69-80

Aragüés R, Puy J, Royo A, Espada JL 2005. Three-year field response of young olive trees (Olea europaea L., cv. Arbequina) to soil salinity: Trunk growth and leaf ion accumulation. Plant Soil 271:265-273.

Ashraf M, Orooj A. 2006.Salt stress effects on growth, ion accumulation and seed oil concentration in an arid zone traditional medicinal plant ajwain (Trachyspermum ammi [L.] Sprague). J Arid Environ. 64(2):209220. 
Benlloch M, Marin L, Fernández-Escobar R.1994.Salt tolerance of various olive varieties. Acta Horticult. 356: 215-217.

Bernstein L.1964. Effects of salinity on mineral composition and growth of plants. Proc. 4th Int. Coll. Plant Anal. Fert. Probl. Bruxelles. Belgium 4: 25-45.

Chartzoulakis KS.2005. Salinity and olive: Growth, salt tolerance, photosynthesis and yield. Agr. Water Manag. 78: $108-121$.

Cimato A, Castelli S, Tattini M, Traversi ML.2010. An ecophysiological analysis of salinity tolerance in olive. Environ. Exp. Bot. 68: 214-221.

Epstein E. 1985. Salt tolerant crops: origins, development and the prospects of the concept. Plant and Soil, 89: 187-198.

Grattan SR Grieves CM.1999. Salinity-mineral nutrient relations in horticultural crops. Scientia Hort. 78 : $127-$ 57.

Gucci R, Tattini M.11997. Salinity tolerance in olive. Hort. Rev. 21: 177-214.

Hasegawa PM, Bressan RA, Zhu JK, Bohnert HJ. 2000. Plant cellular and molecular responses to high salinity. Annu. Rev. Plant Physiol. Plant Mol. Biol., 51: 463-499.

Hassan MM, Seif SA, Morsi ME.2000. Salt tolerance of olive trees. Egyptian J. Hort. 27: 105-116.

Maas EV. 1990. Crop salt tolerance. In: Agricultural Salinity Assessment and Management (KK Tanji, ed), ASCE Manuals and Reports on Engineering Practice No. 71, Am. Soc. Civil Eng., New York .

Maas EV, Hoffman GJ.1977. Crop salt tolerance: current assessment. J. Irrig. Drainage div. 103:115-134.

Management under Salinity and Water Stress, 1999. Technion-Israel Institute of Technology, Haifa, 1-4 March .113-125.

Marín L, Benlloch M, Fernández-Escobar R1995. Screening of olive cultivars for salt tolerance. Scientia Hort. 64: 113-116.

Melgar JC, Mohamed Y, Serrano N, García-Galavís PA, Navarro C, Parra, Benlloch M, Fernández-Escobar R 2009. Long term response of olive tree to salinity. Agric. Water Manage. 96: 1105-1113.

Murillo JM, Lopez R, Fernandez JE, Cabrera F 2000. Olive tree response to irrigation with wastewater from the table olive industry. Irrig Sci. 19:175-180.

Perica S, Goreta S, Selak GV 2008. Growth, biomass allocation, and leaf ion concentration of seven olive (Olea europaea L.) cultivars under increased salinity. Scientia Horticulturae 117: 123-129.

Rallo L, Cuevas J 2008.Fructificación y producción. En: El cultivo del olivo. Barranco, Fernández- Escobar and Rallo. Ediciones Mundi-Prensa y Junta de Andalucía. Madrid.846 pp.

Citation: M. Arshadullah et al., "Impact of Saline Water on Growth of Olive Varieties in Tunnel", International Journal of Research Studies in Biosciences (IJRSB), vol. 6, no. 2, pp. 4-7, 2018. http://dx.doi.org/ 10.20431/2349-0365.0602002

Copyright: (C) 2018 Authors. This is an open-access article distributed under the terms of the Creative Commons Attribution License, which permits unrestricted use, distribution, and reproduction in any medium, provided the original author and source are credited. 